\title{
Effect of Deposition Conditions on the Properties of Pyrolytic Silicon Carbide Coatings for High-Temperature Gas-Cooled Reactor Fuel Particles
}

\author{
D. P. Stinton \\ W. J. Lackey
}

\section{OAK RIDGE NATIONAL LABORATORY}

OPERATED BY UNION CARBIUL CURPURAIION FOR THE ENERGY RESEARCH AND DFVFIOPMFNT ADMINISTRATIONN 


\section{DISCLAIMER}

This report was prepared as an account of work sponsored by an agency of the United States Government. Neither the United States Government nor any agency Thereof, nor any of their employees, makes any warranty, express or implied, or assumes any legal liability or responsibility for the accuracy, completeness, or usefulness of any information, apparatus, product, or process disclosed, or represents that its use would not infringe privately owned rights. Reference herein to any specific commercial product, process, or service by trade name, trademark, manufacturer, or otherwise does not necessarily constitute or imply its endorsement, recommendation, or favoring by the United States Government or any agency thereof. The views and opinions of authors expressed herein do not necessarily state or reflect those of the United States Government or any agency thereof. 


\section{DISCLAIMER}

Portions of this document may be illegible in electronic image products. Images are produced from the best available original document. 


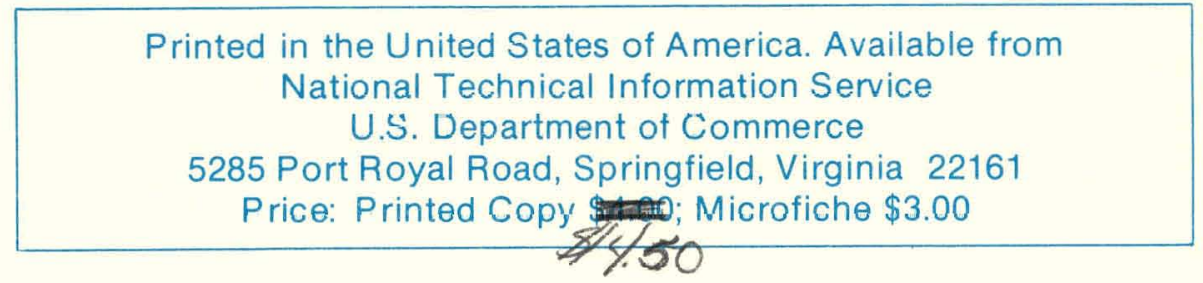

This report was prepared as an account of work sponsored by the United States Government. Neither the United States nor the Energy Research and Development Administration/United States Nuclear Regulatory Commission, nor any of their employees, nor any of their contractors, subcontractors, or their employees, makes any warranty, express or implied, or assumes any legal liability or responsibility for the accuracy, completeness or usefulness of any information, apparatus, product or process disclosed, or represents that its use would not infringe privately owned rights. 
ORNL/TM-5743

Distribution

Category UC-77

Contract No. W-7405-eng-26

METALS AND CERAMICS DIVISION

Thorium Utilization Program (189a OH045)

Fuel Refabrication - Task 300

\section{EFFECT OF DEPOSITION CONDITIONS ON THE PROPERTIES OF PYROLYTIC \\ SILICON CARBIDE COATINGS FOR HIGH-TEMPERATURE GAS-COOLED REACTOR FUEL PARTICLES}

D. P. Stinton and W. J. Lackey

Date Published: October 1977

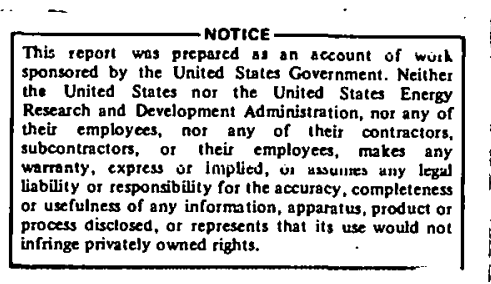

OAK RIDGE NATIONAL LABORATORY

Oak Ridge, Tennessee 37830

operated by

UNION CARBIDE CORPORATION

for the

ENERGY RESEARCH AND DEVELOPMENT ADMINISTRATION 
THIS PAGE

WAS INTENTIONALLY

LEFT BLANK 
CONTENTS

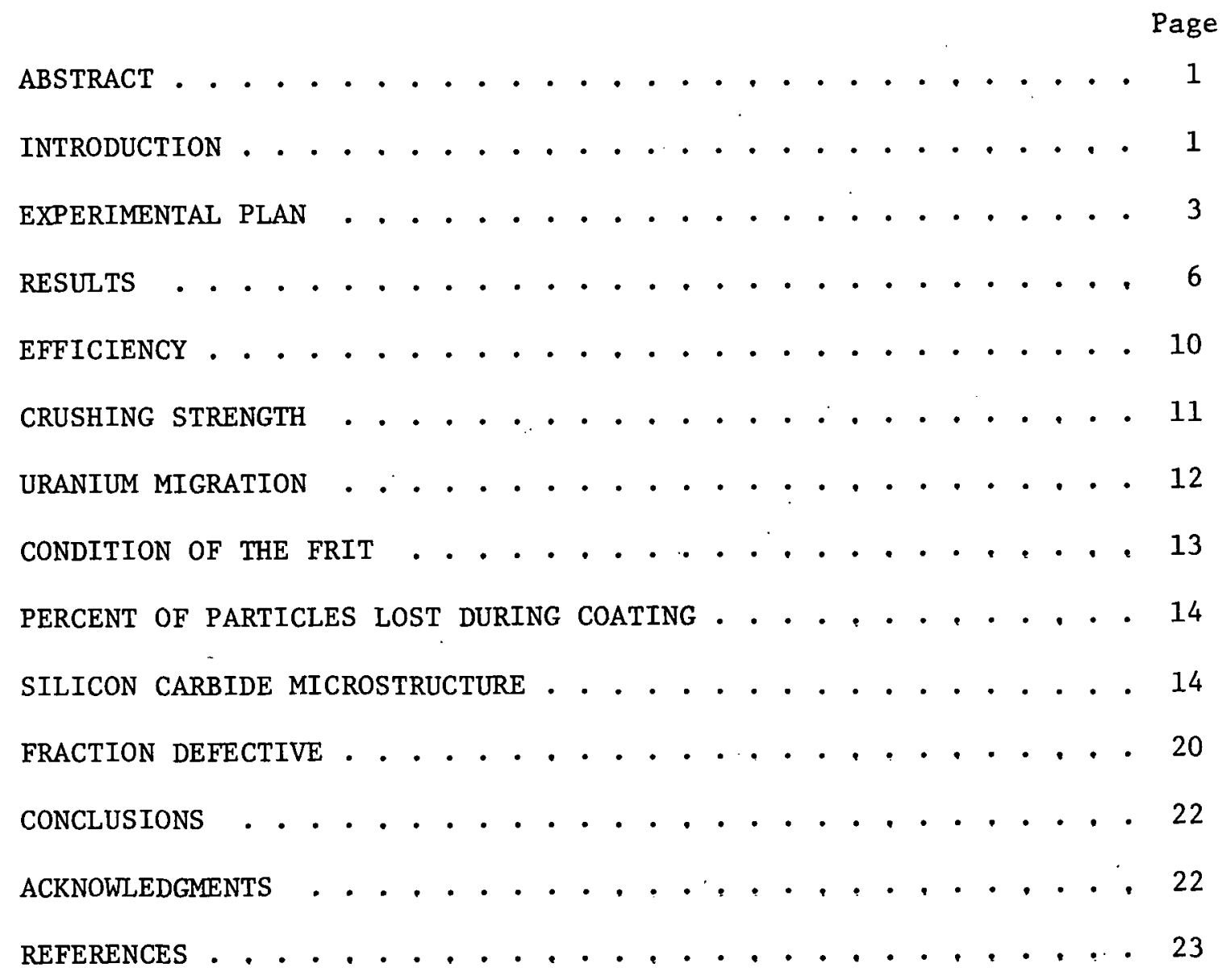


EFFECT OF DEPOSITION CONDITIONS ON THE PROPERTIES OF PYROLYTIC SILICON CARBIDE COATINGS FOR HIGH-TEMPERATURE GAS-COOLED REACTOR FUEL PARTICLES

D. P. Stinton and W. J. Lackey

\begin{abstract}
Silicon carbide coatings on HTGR microsphere fuel act as the barrier to contain metallic fission products. Silicon carbide coatings in this study were applied by the decomposition of $\mathrm{CH}_{3} \mathrm{SiCl}_{3}$ in a 13-cm-diam (5-in.) fluidizedbed coating furnace. The effects of temperature, $\mathrm{CH}_{3} \mathrm{SiCl}_{3}$ supply rate and the $\mathrm{H}_{2}: \mathrm{CH}_{3} \mathrm{SiCl}_{3}$ ratio on coating properties were studied. Deposition temperature was found to control coating density, whole particle crushing strength, coating efficiency, and microstructure. Coating density and microstructure were also partially determined by the $\mathrm{H}_{2}: \mathrm{CH}_{3} \mathrm{SiCl}_{3}$ ratio. From this work, it appears that the rate at. which high quality $\mathrm{SiC}$ can be deposited can be increased from 0.2 to $0.5 \mu \mathrm{m} / \mathrm{min}$.
\end{abstract}

\title{
INTRODUCTION
}

Fuel microspheres for High-Temperature Gas-Cooled Reactors are coated with layers of pyrolytic carbon and silicon carbide (SiC). The uranium bearing fissile fuel is first coated with a porous pyrolytic carbon buffer layer that provides void volume for gaseous fission products and protects outer coatings from fission fragment recoils. The buffer is followed by a silicon carbide layer sandwiched between two layers of high density pyrolytic carbon referred to as the low temperature isotropic (LTI) layer (Fig. 1). A silicon carbide layer is required as a diffusion barrier to retain solid fission products such as cesium, strontium, barium, and several rare earth elements. The silicon carbide layer also acts as a pressure vessel for containing the fission product gases krypton and xenon. 


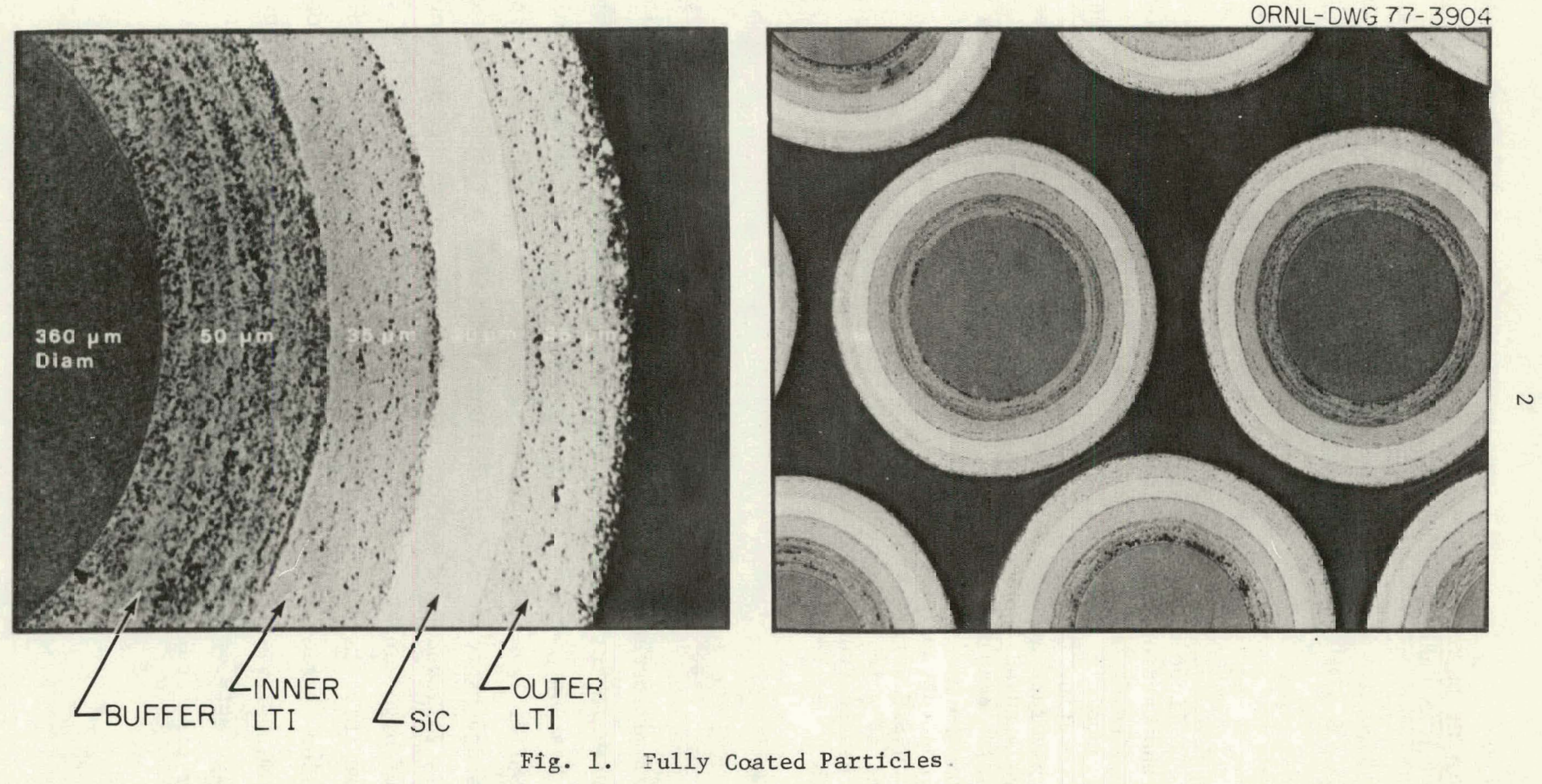


Silicon carbide is typically deposited by the decomposition of of methyltrichlorosilane $\left(\mathrm{CH}_{3} \mathrm{SiCl}_{3}\right)$ in a fluidized-bed coating furnace using hydrogen as the fluidizing gas. Methyltrichlorosilane (MTS) is most frequently used because it has a $1: 1$ molar ratio of silicon to carbon which results in the deposition of a dense stoichiometric coating. The silicon carbide must be of nearly theoretical density to prevent the diffusion of solid fission products through the coating. This work was conducted to determine the influence that process variables have on silicon carbide properties such as density, fraction defective, crushing strength, uranium dispersion from the kernel into the buffer coating layer, coating efficiency, percent of particles lost during processing, and the condition of the porous plate gas distributor after coating. It was also desired to learn if high quality silicon carbide could be deposited at faster rates than previously feasible.

\section{EXPERIMENTAL PLAN}

An experiment was statistically designed (Fig. 2) to study the effects of temperature, MTS flux (MTS flow rate/surface area of the particle charge), and $\mathrm{H}_{2}$ :MTS ratio on various properties. The variables investigated (Table 1 ) were determined to be the most important in experiments conducted by Gyarmati and Nickel, ${ }^{1}$ Federer, ${ }^{2}$ Gulden, ${ }^{3}$ and Voice and Lamb. ${ }^{4}$ These earlier studies yielded important information about coatings deposited in smaller furnaces using a conical gas distributor. The present study made use of a larger diameter, 13-cm, engineering scale coating furnace and a new type of coating gas distributor suitable for scale-up to commercial size equipment.

Coatings in this experiment were deposited using a furnace that has been described previous $1 y \cdot{ }^{5,6}$ It is important to note that temperature is measured by an optical pyrometer focused on the outside of the coating chamber that contains the fluidized bed of particles. The measured temperature is thus somewhat higher than the exact particle bed temperature because of the flow of hydrogen through the particle bed.

The gas distributor used was a contoured porous carbon plate called a frit. Figure 3 shows the frit that is described in more delail 
ORNL-DWG 76-16741R

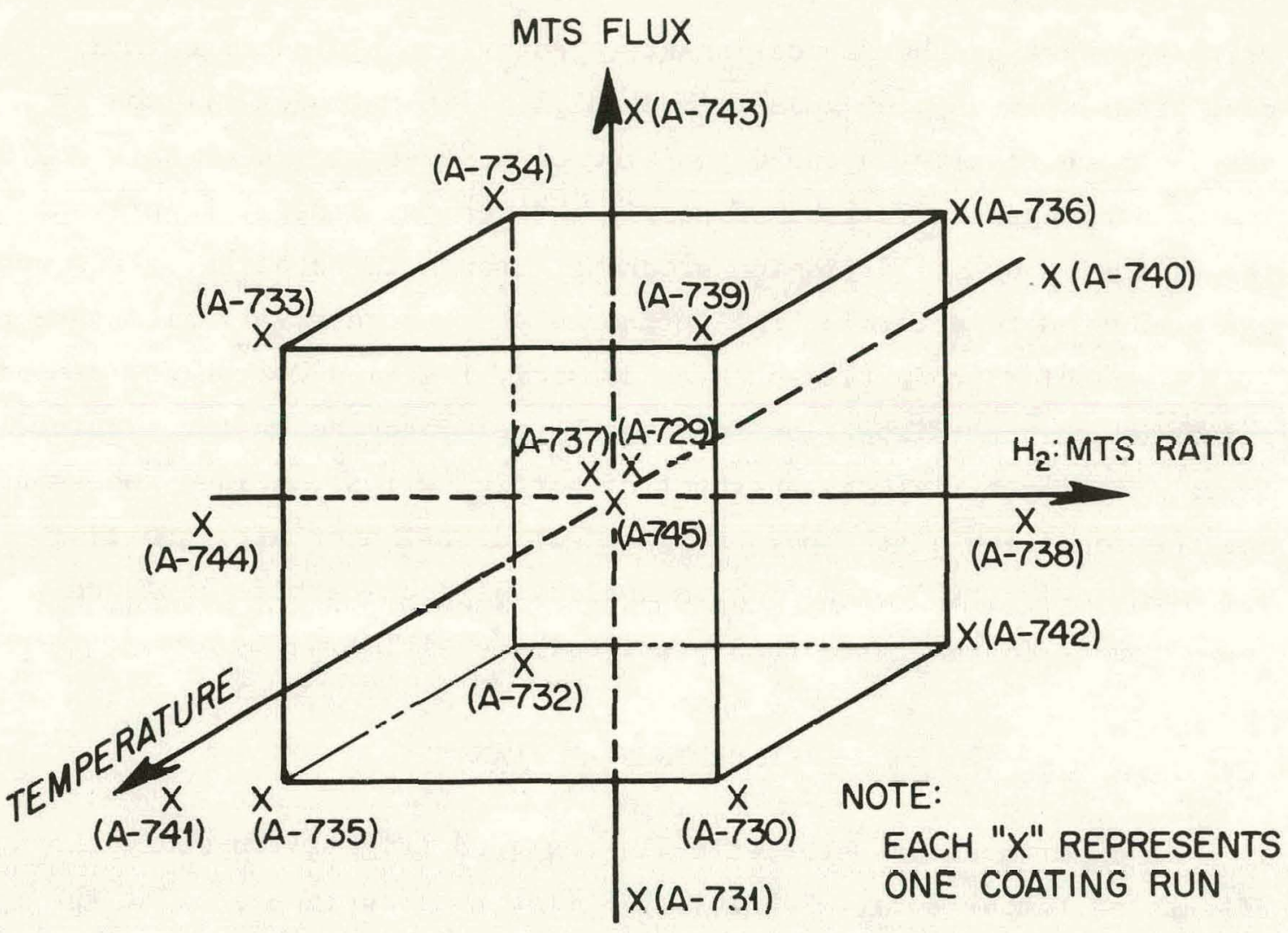

Fig. 2. Schematic Representation of the Experimental Design Used to Investigate the Effect of Temperature, MTS Flux, and $\mathrm{H}_{2}$ :MTS Ratio on the SiC Deposition Proccss. Each " $x$ " represents one coating run. The run number is in parenthesis.

Table 1. Variable Levels for Deposition of Silicon Carbide Cuatings

\begin{tabular}{lccc}
\hline $\begin{array}{c}\text { Location of } \\
\text { Levels of } \\
\text { Fig. 2 }\end{array}$ & $\begin{array}{c}\text { Temperature } \\
\left({ }^{\circ} \mathrm{C}\right)\end{array}$ & $\begin{array}{c}\text { MTS Flux } \\
\left(\mathrm{cm}^{3} / \mathrm{min} \cdot \mathrm{cm}^{2}\right)\end{array}$ & $\begin{array}{r}\mathrm{H}_{2} / \text { MTS } \\
\text { Ratio }\end{array}$ \\
\hline Minimum & 1405 & 0.018 & 11 \\
Cube Face & 1475 & 0.035 & 25 \\
Center Point & 1575 & 0.060 & 45 \\
Cube Face & 1675 & 0.085 & 65 \\
Maximum & 1785 & 0.102 & 79 \\
\hline
\end{tabular}




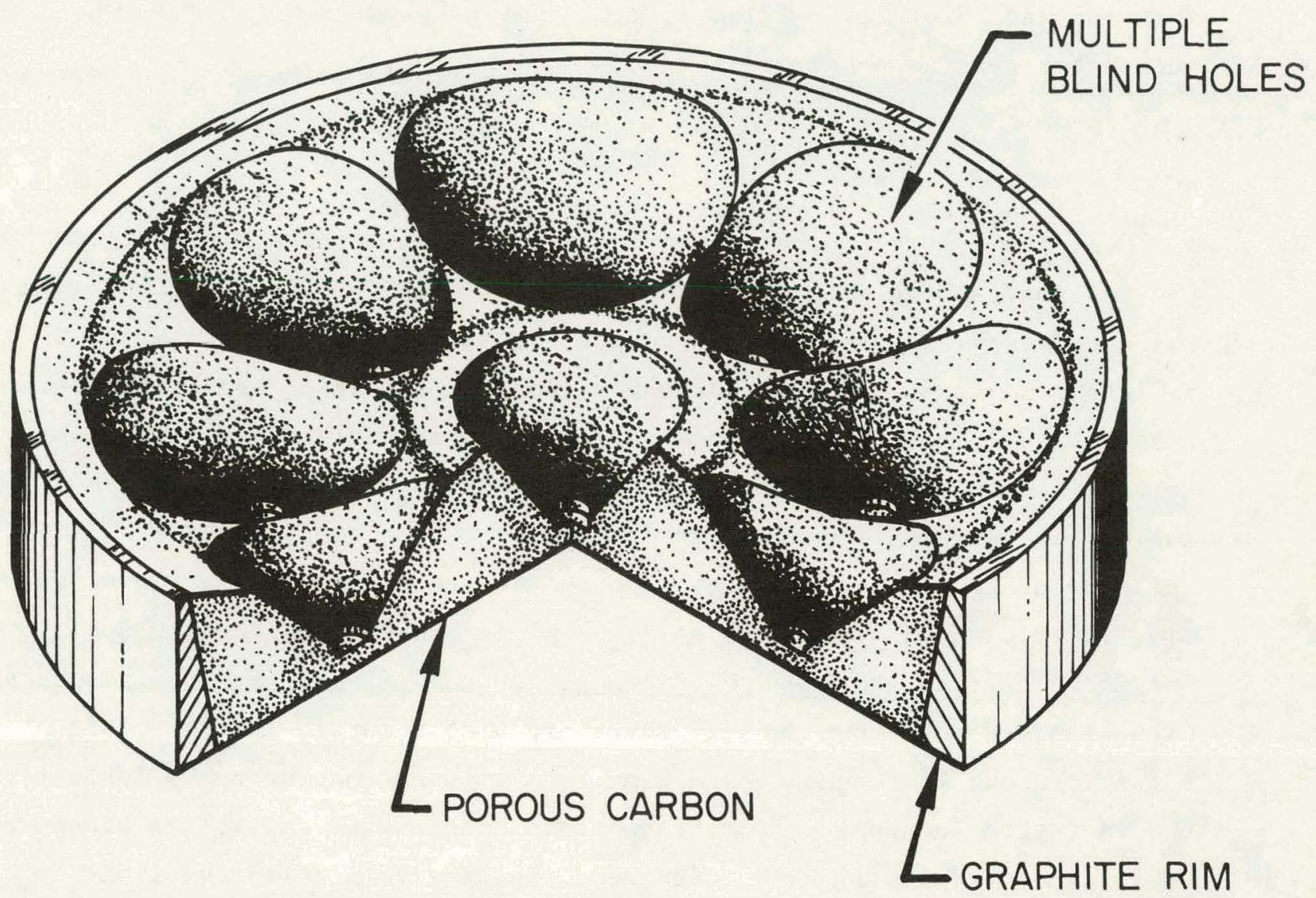

Fig. 3. Porous Plate Gas Distributor. The coating gas passes from below the plate through the thinned regions of the porous carbon into the particle bed. The multiple inlets provide good dispersion of the coating gas.

elsewhere. ${ }^{7,8}$ The method of MTS vapor generation for this work was different from most other silicon carbide coating furnaces. In this furnace, liquid MTS is simply dripped into a line heated to $110^{\circ} \mathrm{C}$ to vaporize the MTS. This line carries the hydrogen fluidizing gas and MTS vapor into the furnace. The $f l u x$ and $H_{2}$ :MTS ratio were controlled by varying the flow rate of hydrogen and the amount of silane metered into this line.

The substrate material onto which the silicon carbide was deposited was a large lot of buffer and LTI coated microspheres of the weak-acid resin type. This is the reference HTCR fissile particle. ${ }^{9,10,11}$ The 
important statistics of the substrate lot are: kernel diameter $-0.0359 \mathrm{~cm}$; coated particle diameter $-0.0518 \mathrm{~cm}$; and particle density $-2.063 \mathrm{~g} / \mathrm{cm}^{3}$. This lot was carefully riffled into batches of about $950 \mathrm{~g}$ each. One such batch was the substrate for each coating run.

\section{RESULTS}

Obtaining a high density coating is the most important objective of the silicon carbide coating operation. Densities in excess of $3.18 \mathrm{~g} / \mathrm{cm}^{3}$, which corresponds to $99 \%$ of theoretical density, are likely required to achieve good irradiation performance. Coating densities are measured by immersing silicon carbide fragments in a liquid gradient density column. ${ }^{12}$ The fragments are prepared by crushing coated particles and collecting large silicon carbide fragments. Carbon is removed from the silicon carbide by low temperature oxidation to prevent formation of an $\mathrm{SiO}_{2}$ layer, and the fragments are then placed in the gradient column. Coating densities are measured by comparing the silicon carbide fragments with standards of known density which are also immersed in the liquid column. About 15 fragments are used from a given coating run. Typically the variation in density from fragment to fragment is small; the standard deviation is typically $0.005 \mathrm{~g} / \mathrm{cm}^{3}$ and thus the $95 \%$ confidence limit on the mean density for 15 fragments is $\pm 0.003 \mathrm{~g} / \mathrm{cm}^{3}$.

The coating densities ranged from 3.137 to $3.200 \mathrm{~g} / \mathrm{cm}^{3}$ (Table 2). A multiple regression analysis of this data showed that density was dependent on the $\mathrm{H}_{2}$ :MTS ratio, temperature, and the temperature squared. The $\mathrm{H}_{2}$ :MTS ratio was found to be significant at the $90 \%$ confidence level while temperature and temperature squared were significant at the $95 \%$ confidence leve1. The curves in Fig. 4 show the general effect that temperature and the $\mathrm{H}_{2}$ :MTS ratio have on the silicon carbide density. These curves were plotted using the equation predicted by the multiple regression analysis mentioned above. This figure shows that density increases from about $3.15 \mathrm{~g} / \mathrm{cm}^{3}$ at $1400^{\circ} \mathrm{C}$ to about $3.195 \mathrm{~g} / \mathrm{cm}^{3}$ at $1625^{\circ} \mathrm{C}$, It then decreases to about $3.17 \mathrm{~g} / \mathrm{cm}^{3}$ by $1800^{\circ} \mathrm{C}$. Higher $\mathrm{H}_{2}:$ MTS ratios produce more dense coatings (Fig. 4). By increasing the $\mathrm{H}_{2}$ :MTS ratio from 25 to 45 or from 45 to 65 , the coating density increased by about 
Table 2. Experimental Conditions and Results for SiC Deposition

\begin{tabular}{|c|c|c|c|c|c|c|c|c|c|c|c|c|}
\hline $\begin{array}{c}\text { Run } \\
\text { Number }\end{array}$ & $\begin{array}{l}\text { MTS Gas Flux } \\
\left(\mathrm{cm}^{3} / \mathrm{min} \cdot \mathrm{cm}^{2} \text {; }\right.\end{array}$ & $\mathrm{H}^{2} / \mathrm{GTS}$ & $\begin{array}{l}\text { Temperature } \\
\left({ }^{\circ} \mathrm{C}\right)\end{array}$ & $\begin{array}{l}\text { Deposicion } \\
\text { Race } \\
(\mathrm{dm} / \mathrm{m} \leq \mathrm{n})\end{array}$ & $\begin{array}{l}\text { Immersion } \\
\text { Densicy } \\
\left(\mathrm{g} / \mathrm{cm}^{3}\right)\end{array}$ & $\begin{array}{l}\text { Fraztion } \\
\text { Defective by } \\
\text { Hg Intrusion }\end{array}$ & $\begin{array}{c}\text { Fraction } \\
\text { Defective by } \\
\text { Burn and } \\
\text { Aqueous Lea:h }\end{array}$ & $\begin{array}{l}\text { Particle } \\
\text { Crushing } \\
\text { Strength } \\
\quad(1 b)\end{array}$ & $\begin{array}{c}\text { Uranium } \\
\text { Disfersiona }\end{array}$ & $\begin{array}{l}\text { Condition } \\
\text { of Frit }\end{array}$ & $\begin{array}{c}\text { Efficiency } \\
(\%)\end{array}$ & $\begin{array}{l}\text { Particles } \\
\text { Lost } \\
(\%)\end{array}$ \\
\hline$A-728$ & 0.060 & 45 & 1575 & 0.26 & 3.200 & $3.16 \times 10^{-4}$ & $3.7 \times 10^{-6}$ & 2.89 & 1 & 2 & 77.40 & 0.56 \\
\hline$A-730$ & 0.035 & $6 j$ & 1675 & 0.14 & 3.199 & $1.99 \times 10^{-4}$ & $2.2 \times 10^{-2}$ & 2.30 & 3 & 4 & 72.61 & 0.18 \\
\hline$A-731$ & 0.018 & 45 & 1575 & 0.07 & 3.199 & $8.54 \times 10^{-5}$ & $5.5 \times 10^{-5}$ & 3.03 & 4 & 5 & 77.43 & 2.27 \\
\hline$A-732$ & 0.034 & 25 & 1475 & 0.17 & 3.178 & $5.69 \times 10^{-5}$ & $3.0 \times 10^{-5}$ & 2.95 & 1 & 2 & 83.42 & 0.60 \\
\hline$A-733$ & 0.085 & 25 & 1675 & 0.35 & 3.163 & $5.51 \times 10^{-4}$ & $4.0 \times 10^{-4}$ & 2.64 & 3 & 2 & 76.57 & 2.10 \\
\hline A-734 & 0.085 & 25 & 1475 & 0.39 & 3.181 & $2.10 \times 10^{-4}$ & $1.1 \times 10^{-4}$ & 2.83 & 1 & 1 & 84.14 & 1.30 \\
\hline$A-735$ & 0.335 & 25 & 1675 & 0.13 & 3.185 & $2.33 \times 10^{-3}$ & $5.4 \times 10^{-3}$ & 2.14 & 5 & 5 & 69.78 & $5.15^{c}$ \\
\hline$A-736$ & 0.085 & 65 & 1475 & 0.37 & 3.174 & $4.45 \times 10^{-4}$ & $1.0 \times 10^{-4}$ & 2.77 & 3 & 2 & 81.85 & 0.86 \\
\hline$A-737$ & 0.060 & 45 & 1575 & 0.25 & 3.197 & $4.82 \times 10^{-5}$ & $3.6 \times 10^{-5}$ & 2.83 & 2 & 3 & 82.64 & 1.90 \\
\hline$A-738$ & 0.060 & 79 & 1575 & 0.28 & 3.191 & $3.63 \times 10^{-4}$ & $2.4 \times 10^{-5}$ & 2.85 & 4 & 3 & 84.48 & 1.58. \\
\hline A-739 & 0.085 & $E S$ & 1675 & 0.37 & 3.196 & $1.08 \times 10^{-4}$ & $2.2 \times 10^{-5}$ & 2.37 & 4. & 3 & 82.16 & 1.12 \\
\hline$A-740$ & 0.060 & 45 & 1405 & 0.27 & 3.137 & $3.09 \times 10^{-4}$ & $6.2 \times 10^{-5}$ & 2.71 & 1 & 1 & 79.41 & 0.82 \\
\hline$A-741$ & 0.060 & 45 & 1785 & 0.24 & 3.182 & $1.72 \times 10^{-3}$ & $1.6 \times 10^{-4}$ & 1.96 & 5 & 4 & 69.86 & 1.24 \\
\hline$A-742$ & 0.035 & ES & 1475 & 0.15 & 3.192 & $6.01 \times 10^{-4}$ & $4.2 \times 10^{-5}$ & 2.92 & 4 & 4 & 83.96 & 1.75 \\
\hline$A-743$ & 0.102 & cs & 1575 & 0.46 & 3.196 & $3.51 \times 10^{-4}$ & $3.6 \times 10^{-5}$ & 3.03 & 2 & 4 & 85.92 & 1.29 \\
\hline A-744 & 0.060 & 1.1 & 1575 & 0.25 & 3.178 & $4.86 \times 10^{-4}$ & $1.3 \times 10^{-4}$ & 2.89 & 2 & 4 & 73.94 & -0.30 \\
\hline$A-745$ & 0.060 & 4.5 & 1575 & 0.25 & 3.196 & $7.35 \times 10^{-4}$ & $3.1 \times 10^{-5}$ & 2.81 & 2 & 3 & 76.43 & -0.82 \\
\hline
\end{tabular}

${ }^{a}$ Denotes the least dispersion.

${ }^{b}$ Denotes the best cond:tion of the frit.

c portion of bat:h was not weigted. 


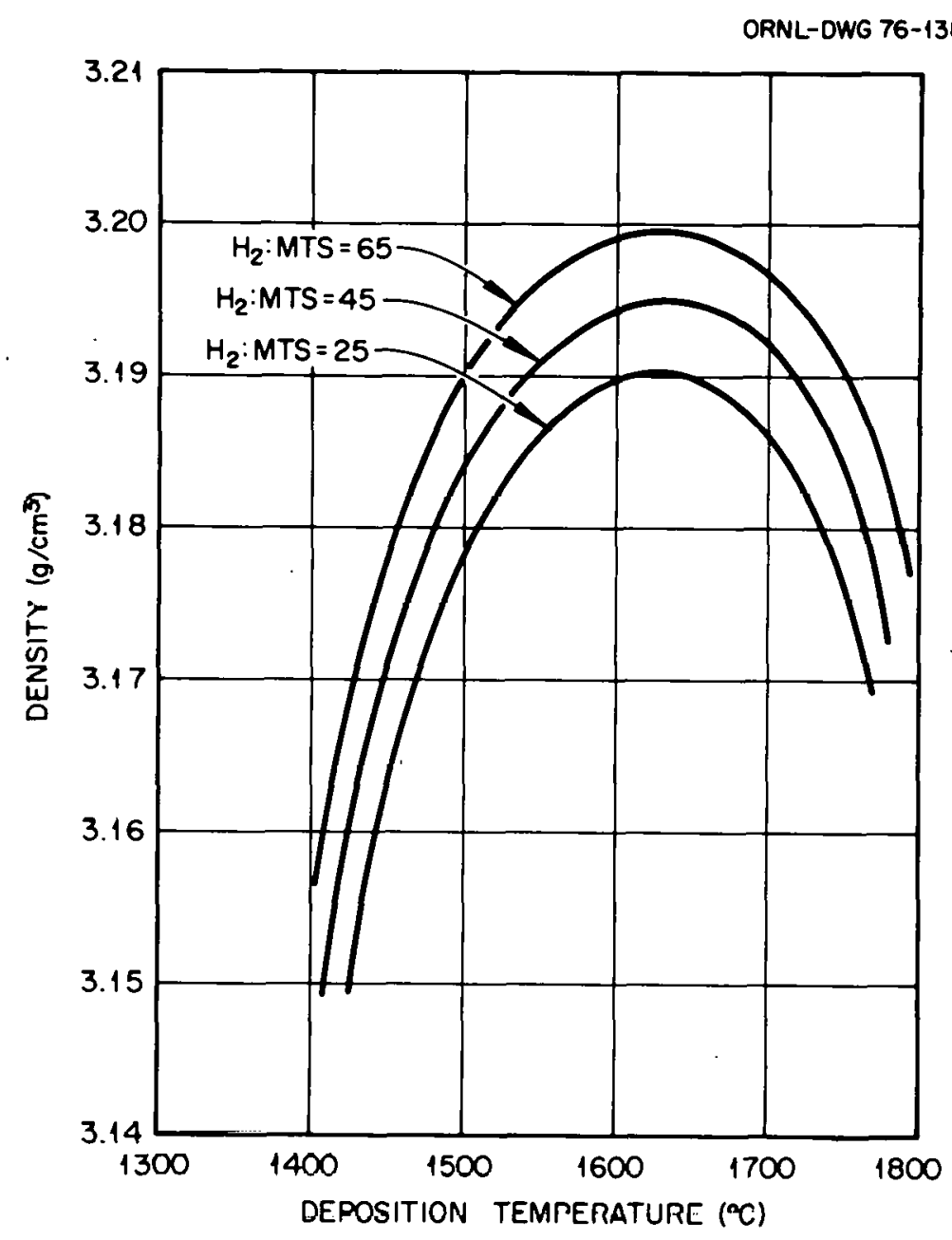

Fig. 4. Correlation of SiC Density with Temperature and $\mathrm{H}_{2}$ :M'l's Ratio. A denstty value greater than $3.18 \mathrm{~g} / \mathrm{cm}^{3}$ is desired.

$0.005 \mathrm{~g} / \mathrm{cm}^{3}$. These results agree closely with those from studies conducted with smaller coaters by Gyarmati and Nirkel ${ }^{1}$ and Federer. ${ }^{2}$

The deposition rate does not affect the coating density for the equipment and process conditions employed. Coatings with-densities of $3.1 .95 \mathrm{~g} / \mathrm{cm}^{3}$ or greater were deposited at rates of $0.07,0.14,0.26$, 0.37 , and $0.46 \mu \mathrm{m} / \mathrm{min}$. An additional coating run was recently made after the statistically designed experiment to verify that high density coatings could be deposited at fast rates provided suitable process conditions were used, For this extra run the deposition rate was $0.48 \mu \mathrm{m} / \mathrm{min}$ and a density of $3.191 \mathrm{~g} / \mathrm{cm}^{3}$ was obtained. From these results, it appears that high density coatings can now be produced in a 13-cm-diam (5-in.) coater at deposition rates up to about $0: 50 \mu \mathrm{m} / \mathrm{min}$. 
Previous experience in similarly depositing silicon carbide with this furnace using a single inlet cone to distribute the gas rather than the frit had shown that unacceptably low density coatings were obtained at deposition rates exceeding 0.15 to $0.20 \mu \mathrm{m} / \mathrm{min}$. It appears that use of the frit type gas distributor is responsible for the attainment of high coating densities at high deposition rates. Future work will be directed toward increasing the deposition rate even further with the frit gas distributor.

The average standard deviation of the coating density for these batches was found to be quite low $\left(0.005 \mathrm{~g} / \mathrm{cm}^{3}\right)$. Specifications for silicon carbide coated particles might require, for example, that 99\% of the particles have silicon carbide coatings with a density greater than $3.17 \mathrm{~g} / \mathrm{cm}^{3}$. A typical batch having a mean silicon carbide density of 3.195 and a standard deviation of 0.005 has $99 \%$ of the coatings with a density greater than 3.183 (Fig. 5). With this low standard deviation,

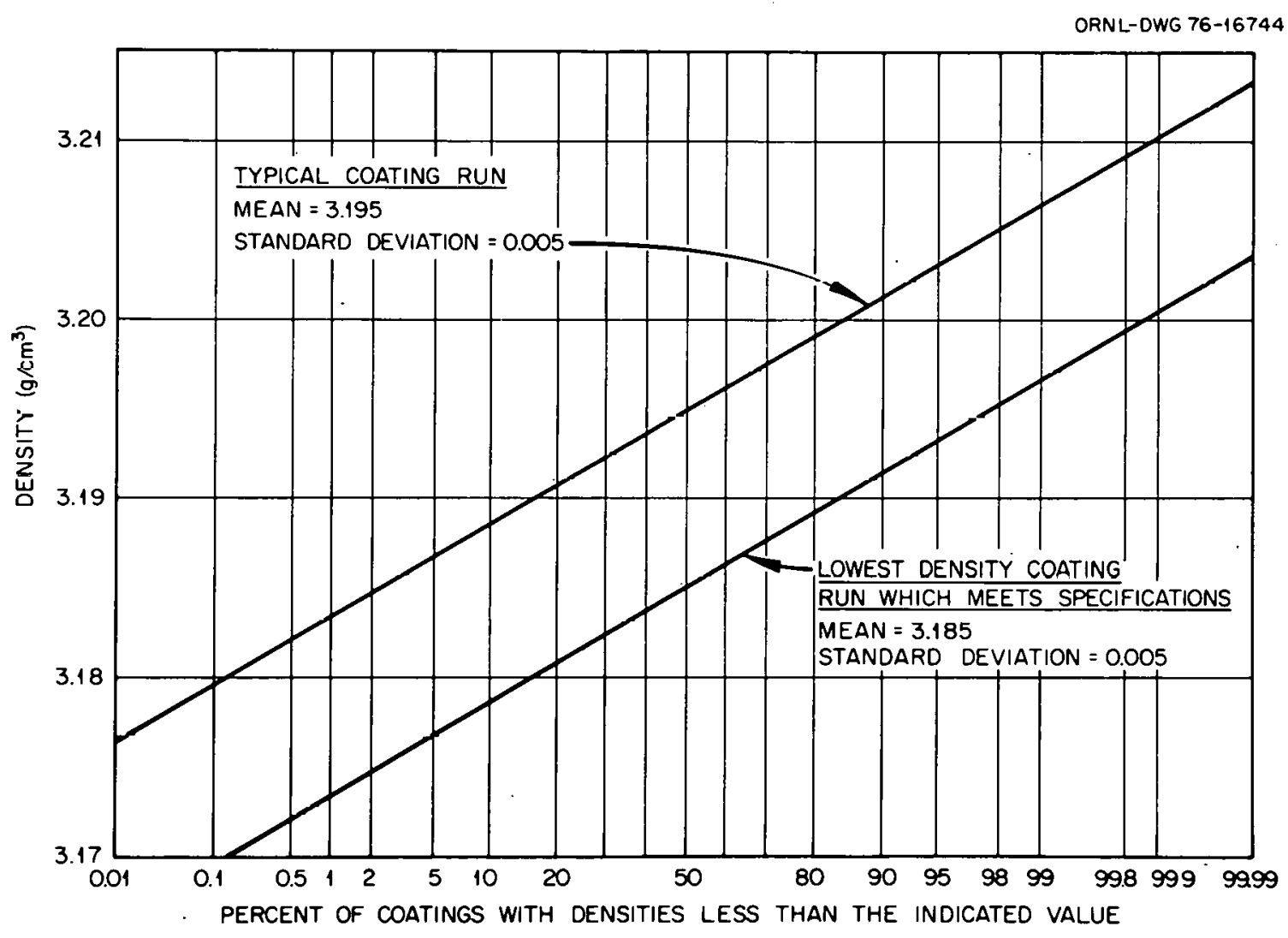

Fig. 5. Particlc-to-Particle Variation in SiC Density. 
the mean can drop to 3.185 and still $99 \%$ of the coatings will have densities above $3.173 \mathrm{~g} / \mathrm{cm}^{3}$.

\section{EFFICIENCY}

All of the silicon and carbon present in the MTS coating gas does not end up as SiC coatings on the particles. Some of the gas leaves the furnace either without decomposing or after only partial decomposition. Also, some of the solid silicon carbide which is formed deposits on the frit and furnace liner. The term efficiency, as used here, refers to the percentage of SiC in the input coating gas which ends up as SiC coating on the particles. The efficiency observed in this study ranged from about 70 to $86 \%$ (Table 2). The deposition temperature has a large effect on efficiency (Fig. 6). An increase in temperature above $1475^{\circ} \mathrm{C}$

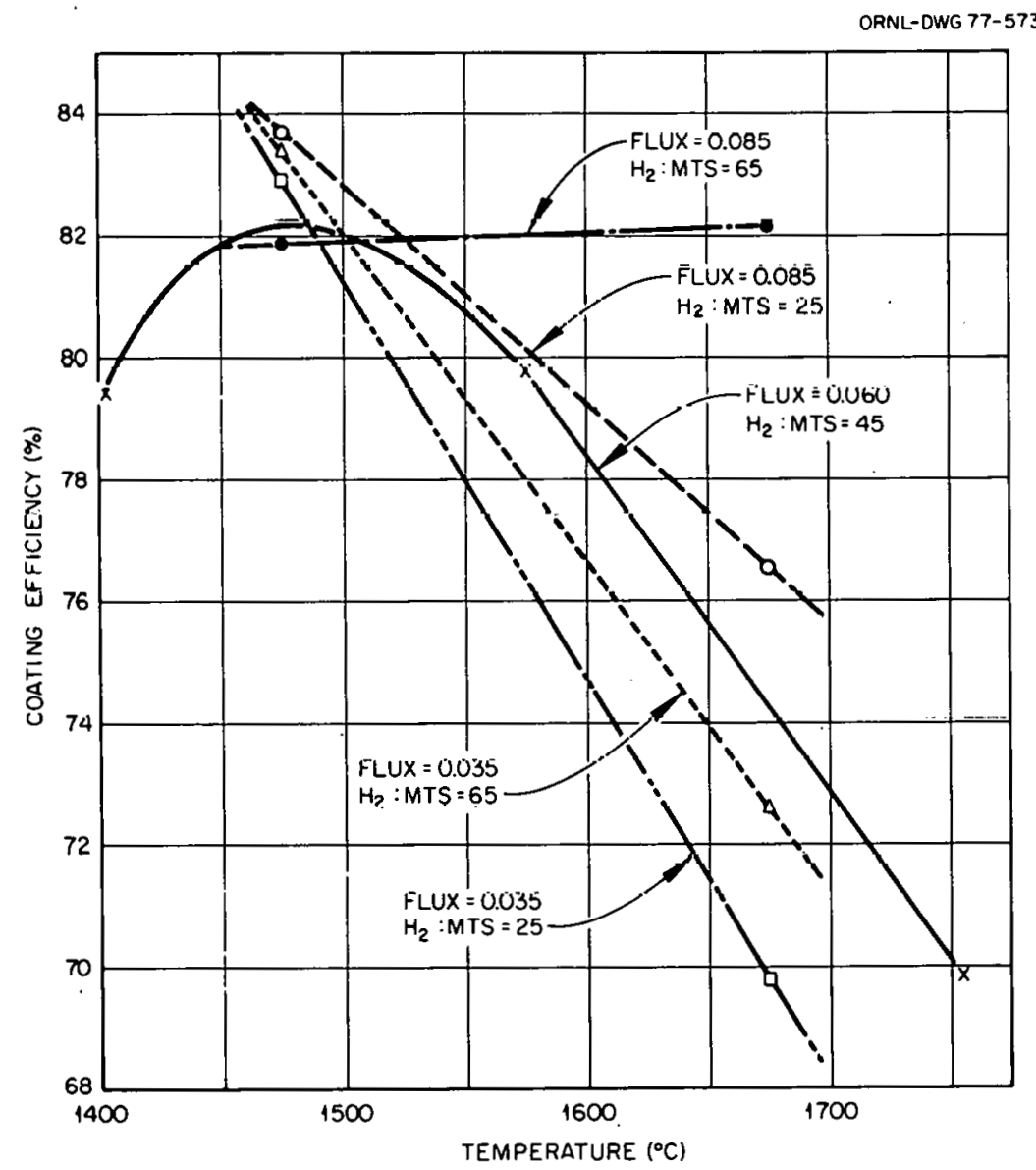

Fig. 6. Effect of Temperature on the Efficiency. of the SiC Deposition Process. The plotted lines are for constant flux and $\mathrm{H}_{2}$ :MTS ratio. 
causes a decrease in efficiency. From the run made at $1405^{\circ} \mathrm{C}$ it appears that efficiency also decreases below $1475^{\circ} \mathrm{C}$. An analysis of the data showed that temperature was statistically significant at the $95 \%$ confidence level. The analysis also showed that flux and the $\mathrm{H}_{2}$ :MTS ratio affected efficiency. Higher fluxes and higher $\mathrm{H}_{2}$ :MTS ratios produced higher coating efficiencies (Fig. 6). However, the effects of flux and $\mathrm{H}_{2}:$ MTS ratio were smaller than the temperature effect.

The efficiency of one silicon carbide run made using the frit in a $24-\mathrm{cm}$-diam coater was $90 \%$. This indicates that efficiency increases with increasing coater size which is consistent with work of Gyarmati and Nickel with conical gas distributors since they observed a higher efficiency for a 8-cm-diam coater than for a 5-cm-diam one.

\section{CRUSHING STRENGTH}

Whole particle crushing strength ${ }^{13}$ is an important property of HTGR fuel particles because the particles must withstand considerable stresses generated during pneumatic particle transfer and fuel rod fabrication. Also, strong silicon carbide is needed to withstand the high gas pressure generated within the particle during irradiation. Crushing strengths are measured by placing an intact particle between two flat plates and determining the load required to initiate fracture. Crushing strengths have been measured on each batch of particles coated in this experiment (Table 2).

The data showed that crushing strength strongly depends on deposition temperature. The maximum crushing strength is produced at a temperature near $1500^{\circ} \mathrm{C}$ (Fig. 7). A multiple regression analysis of the data showed that (temperature) ${ }^{2}$ and temperature were significant at $99 \%$ confidence level. The decrease in strength with increasing deposition temperature is consistent with results of Bongartz et $a 1^{13}$ and with results which show the crushing strength of silicon carbide soated particles decreases on annealing at $1800^{\circ} \mathrm{C}$ (ref. 14). As will be discussed later, the higher the temperature to which the silicon carbide has been exposed the larger the grain size. Thus, given the usual correlation between strength and grain size, i.t is not surprising that strength decreases with increasing exposure temperature. 
ORNL-DWG 76-13890R1

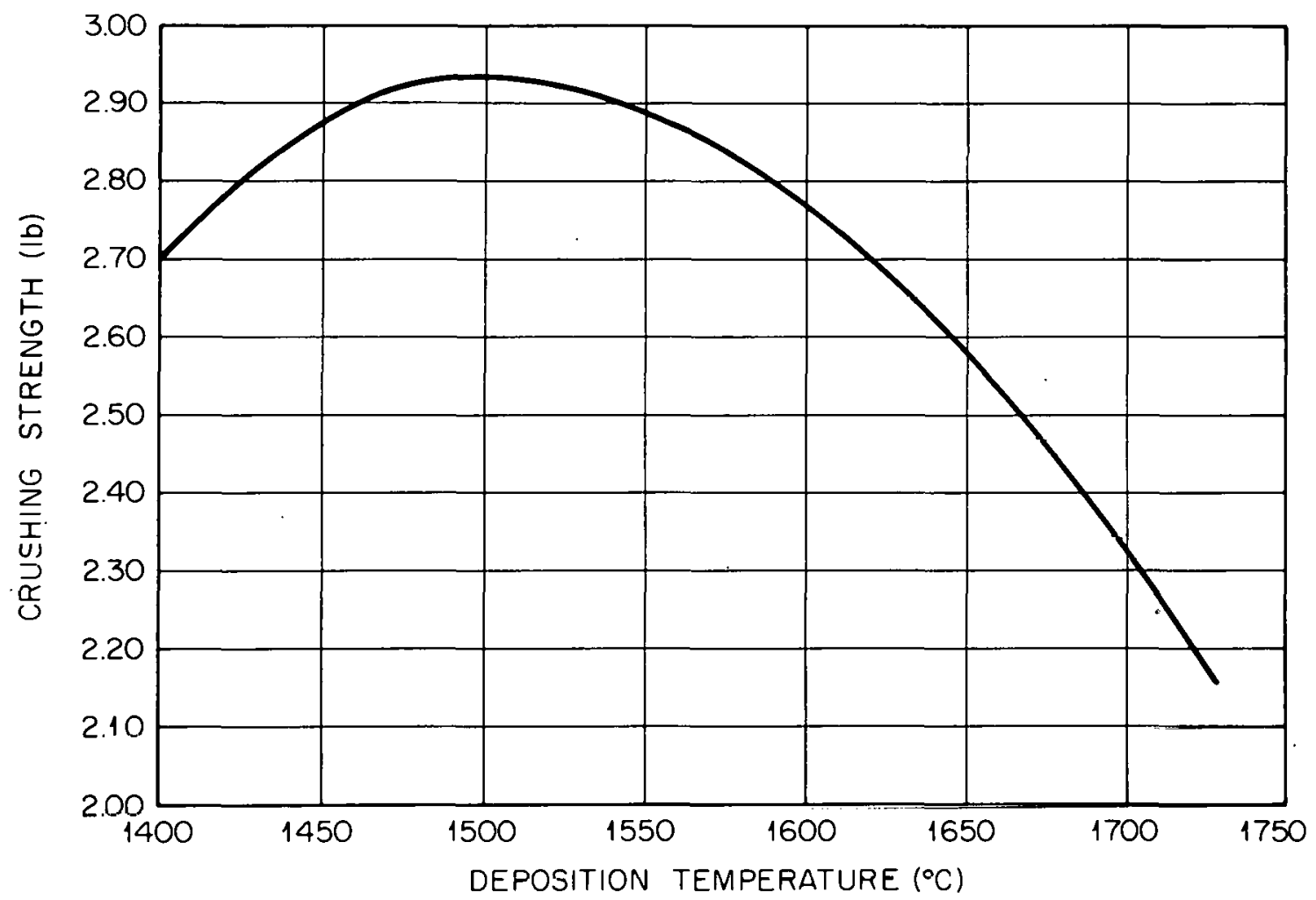

Fig. 7. Correlation of SiC Crushing Strength and Deposition Temperature.

\section{URANIUM MIGRATION}

Under some processing conditions, a portion of the uranium in the fuel kernel has been found to migrate into the buffer coating layer. ${ }^{15}$ The presence of uranium in the buffer could conceivably lead to poor irradiation performance although experience is to the contrary. However, as a precautionary measure uranium migration should be minimized. Uranium dispersion into the buffer is thought to be caused by the reaction of chlorine with $\mathrm{UC}_{2}$ and to a lesser extent with $\mathrm{UO}_{2}$ present in the kernel. ${ }^{15}$ There are two possible sources of chlorine during coating with the $13-\mathrm{cm}$ furnace being used here. One is back-diffusion of $\mathrm{C}_{2} \mathrm{Cl}_{4}$ vapor from a scrubber used to remove soot and tars from the coater off-gas. A second possible source is the $\mathrm{HCl}$ produced by the decomposition of $\mathrm{CH}_{3} \mathrm{SiCl}_{3}$ during silicon carbide coating.

Uranium dispersion into the buffer has been studied in relation to three coating parameters. For each coating run, approximately 100 particles 
were examined by $x$-ray microradiography. ${ }^{16}$ Uranium dispersion into the buffer layer of each particle was classified according to the type of dispersion present. ${ }^{15}$ Using this classification scheme, each batch was placed into groups according to the severity of uranium migration. The groups ranged from type one which showed the least dispersion up to type five. Dispersion was found to correlate with temperature and the $\mathrm{H}_{2}$ :MTS ratio (Table 2). Lower coating temperatures $\left(1475^{\circ} \mathrm{C}\right.$ ) provided a significantly lower amount of dispersion than did the higher coating temperatures $\left(1675^{\circ} \mathrm{C}\right)$ (Fig. 8). Higher $\mathrm{H}_{2}$ :MTS ratio decreased the slope of the lines on the dispersion versus temperature graph. Probably the $\mathrm{H}_{2}$ :MTS effect is in reality caused by lower bed temperatures resulting from the use of high hydrogen flow rates. The arbitrary grading scale causes a large amount of scatter in the data (Fig. 8).

\section{CONDITION OF THE FRIT}

In this study a new frit was used for each coating run. The condition of the frit after use was examined for each run. A scale was set up to

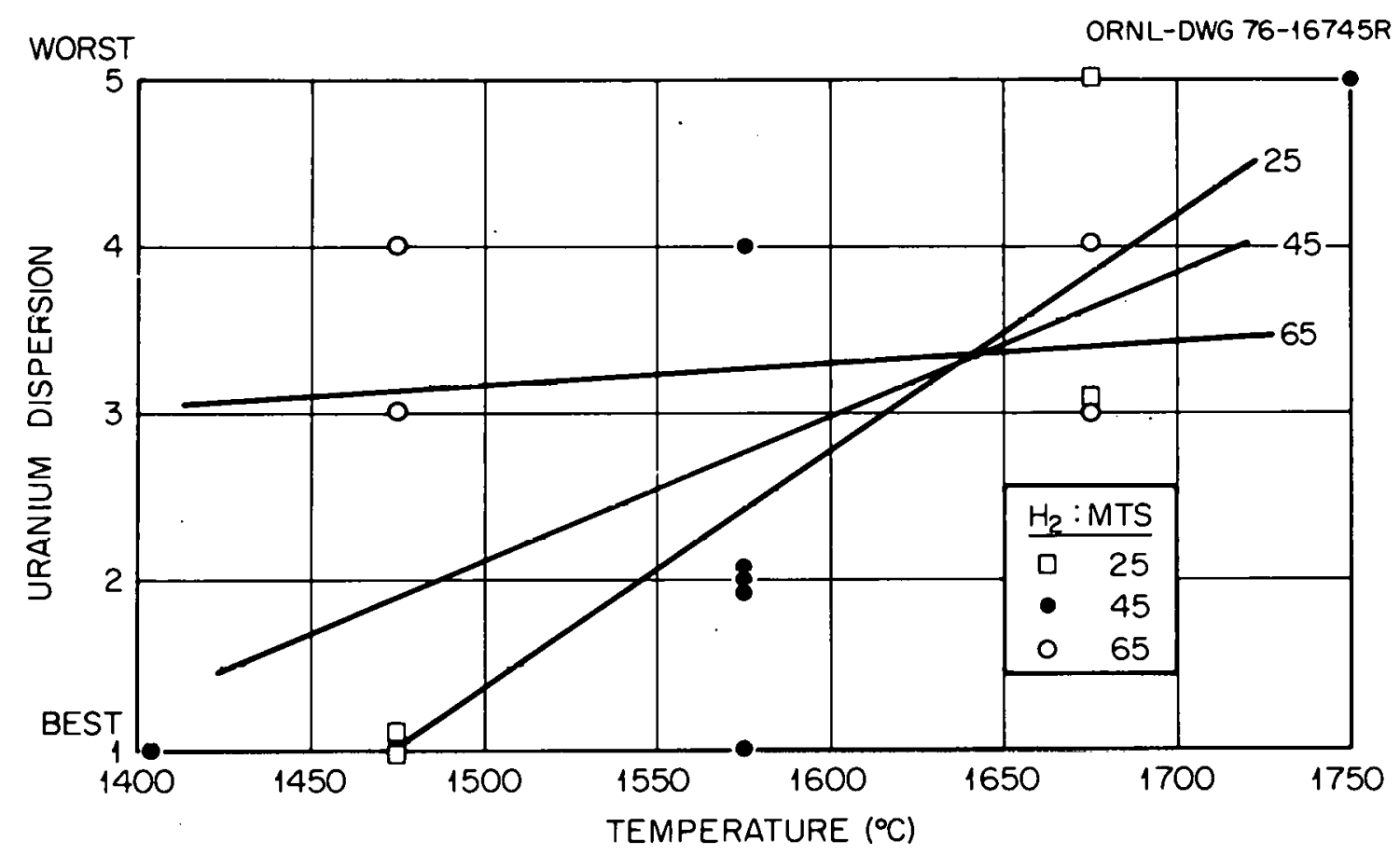

Fig. 8. Influence of Temperature and $\mathrm{H}_{2}$ :MTS Ratio on the Extent of Urantum Dispersion frum the Kernel into lhe Buffer Coating. 
grade the appearance of the frit after coating. The grade was determined by comparing the number of particles that stuck to the frit and the location of the stuck particles. The scale ranged from one to five with one representing the fewest particles stuck to the frit (Fig. 9).

The parameters that affected the condition of the frit were found to be MTS flux and temperature (Table 2). A statistical analysis showed that both temperature and MTS flux were significant at the $95 \%$ confidence level. Higher MTS fluxes and lower temperatures produce frits in the hest condition (Fig. 10).

\section{TERGENT OF TARTICLES LOST DURING COATING}

The percent of particles loet during coating bccauoc of the adherence of particles to the coater interior or from being blown out of the furnace was measured for each coating run (Table 2). There was no correlation with any of the coating variables. There was also no correlation between the total gas flow and the percent of particles lost. The formula used to calculate the loss of particles is:

$\%$ Lost $=100-\frac{\text { No. Particles } / g \text { after coating } \times \text { Batch Weight out }}{\text { No. Particles } / g \text { before coating } \times \text { Batch Weight in }} 100$.

The number of particles per gram was determined by carefully counting the number of particles in the sample $(\sim 1 \mathrm{~g})$ with an automatic particle counter. ${ }^{17}$ This sample was then weighed to $0.1 \mathrm{mg}$ accuracy. Apparently the result of inaccuracy in one or more of the measurements is greater than the effect of the variables because several values are less than $0 \%$ (Table 2).

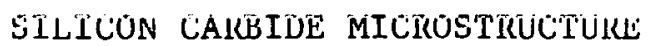

The microstructures of the coating runs made in this study have been. examined using standard ceramographic techniques. The etchant ${ }^{18}$ used to delineate the grain structure was a mixture of $\mathrm{NaOH}$ and $\mathrm{K}_{3} \mathrm{Fe}(\mathrm{CN})_{6}$. Saturated water solutions of each chemical are mixed in equal volume ratios. The mixture is then heated to about $110^{\circ} \mathrm{C}$ and the samples are etched for about five minutes. 
ORNL-DWG 76-16743R

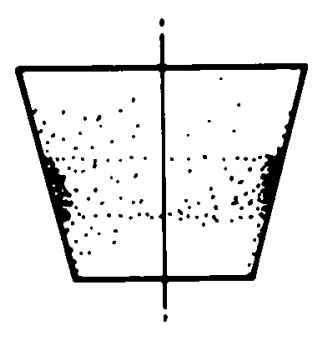

1. VERY FEW PARTICLES STUCK TO FRIT.

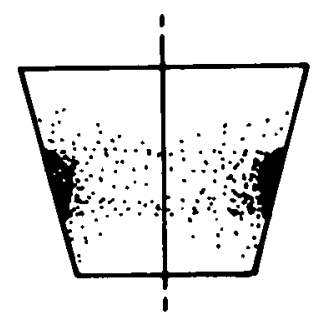

2. FEW PARTICLES STUCK TO FRIT.

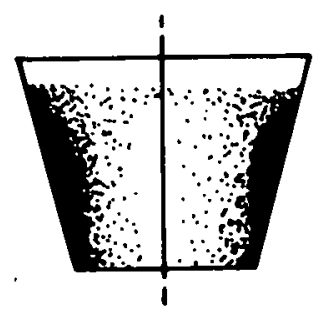

\section{MANY PARTICLES} STUCK TO FRIT, BUT NO CONSTRICTION OF HOLE.

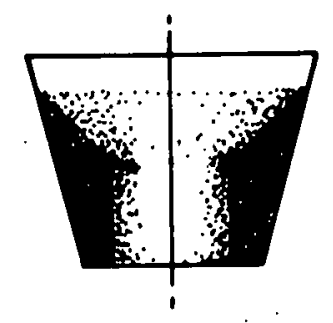

4. MANY PARTICLES STUCK TO FRIT, CAUSING SLIGHT CONSTRICTION OF HOLE.

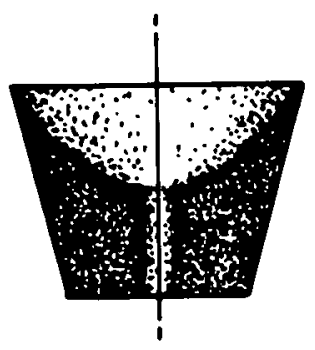

5. MANY PARTICLES STUCK TO FRIT, CAUSING LARGE CONSTRICTION OF HOLE.

Fig. 9. Grading Scale for Condition of Frit. The relative degree of obstruction of the blind holes of the frit is divided into five categories. 
WORST

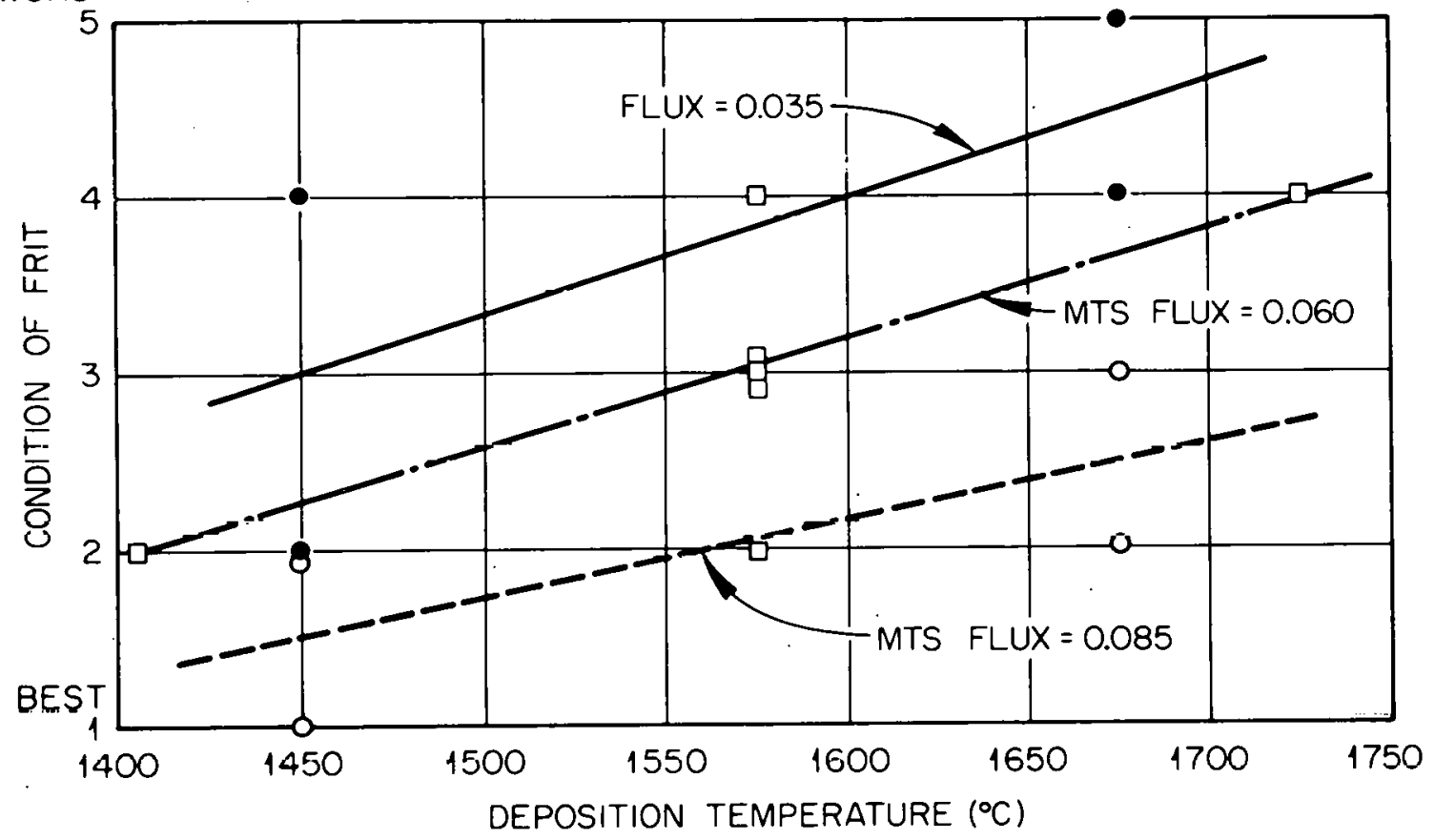

Fig. 10. Correlation of Frit Condition with Deposition Temperature and MTS Flux.

Several coating variables had marked effects on the microstructure of the SiC. The $\mathrm{H}_{2}$ :M'S ratio had a drastic effect. Figure 11 shows two microstructures produced with a low $\mathrm{H}_{2}$ :MTS ratio, 25. The highly banded fine grain structure is typical of low $\mathrm{H}_{2}$ :M'l'S ratios. Higher fluxes caused wider bands and slightly larger grains [Fig. 11(b)]. These coatings typicaily have à lôw dènsity of ảbout $3.18 \mathrm{~g} / \mathrm{cm}^{3}$. Several theories ${ }^{1,4}$ have been proposed for the origin of these bands, but none has been general1y accepted. Coatings produced with $\mathrm{H}_{2}$ :MTS ratios of 45 or greater do not have as many of the bands (Fig. 12).

Temperature is another parameter that had a noticeable effect on the microstructure. Low temperatures $\left(1400^{\circ} \mathrm{C}\right)$ produced highly banded structures and the bands were very convoluted (Fig. 13). The convoluted bands and fine grain sizes are typical of low temperature deposits regardless of the $\mathrm{H}_{2}$ :MTS ratio. These coatings have densities lower than $3.18 \mathrm{~g} / \mathrm{cm}^{3}$. Coatings deposited at higher temperatures (about $1575^{\circ} \mathrm{C}$ ) with $\mathrm{H}_{2}$ :MTS ratios of 45 show an intermediate grain size (Fig. 12): These coatings show only a small number of bands and have a high density of 

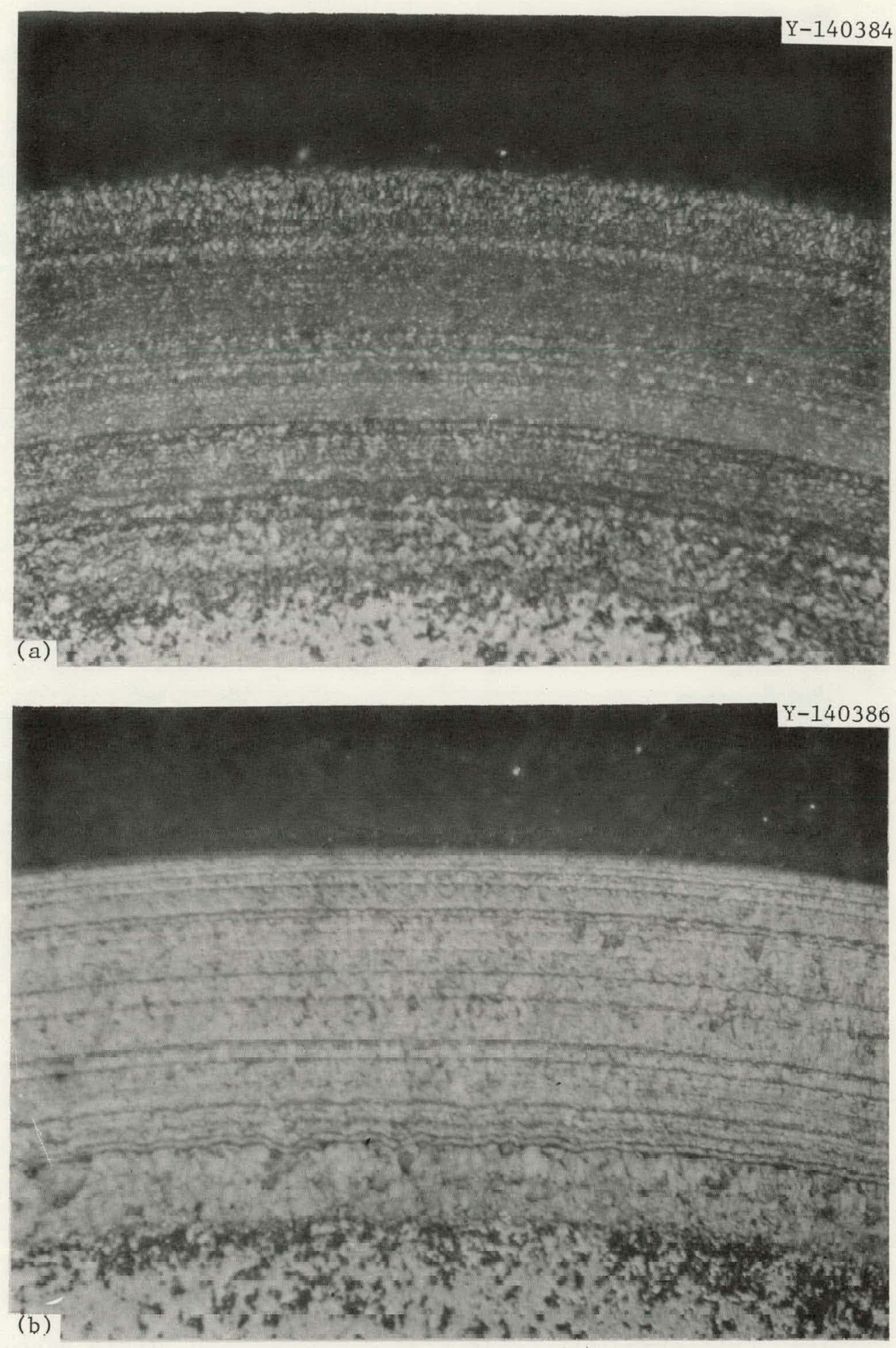

Fig. 11. Highly Banded Fine Grain Structure of Coatings Deposited Using a Low Value, 25, for the $\mathrm{H}_{2}$ :MTS Ratio. (a) Run A-732, Flux = $0.035 \mathrm{~cm}^{3} / \mathrm{min} \cdot \mathrm{cm}^{2}$; (b) Run A-734, Flux $=0.085 \mathrm{~cm}^{3} / \mathrm{min} \cdot \mathrm{cm}^{2}$. The deposition temperature was $1475^{\circ} \mathrm{C}$ for both coatings. $1500 \times$. Reduced $7 \%$. 

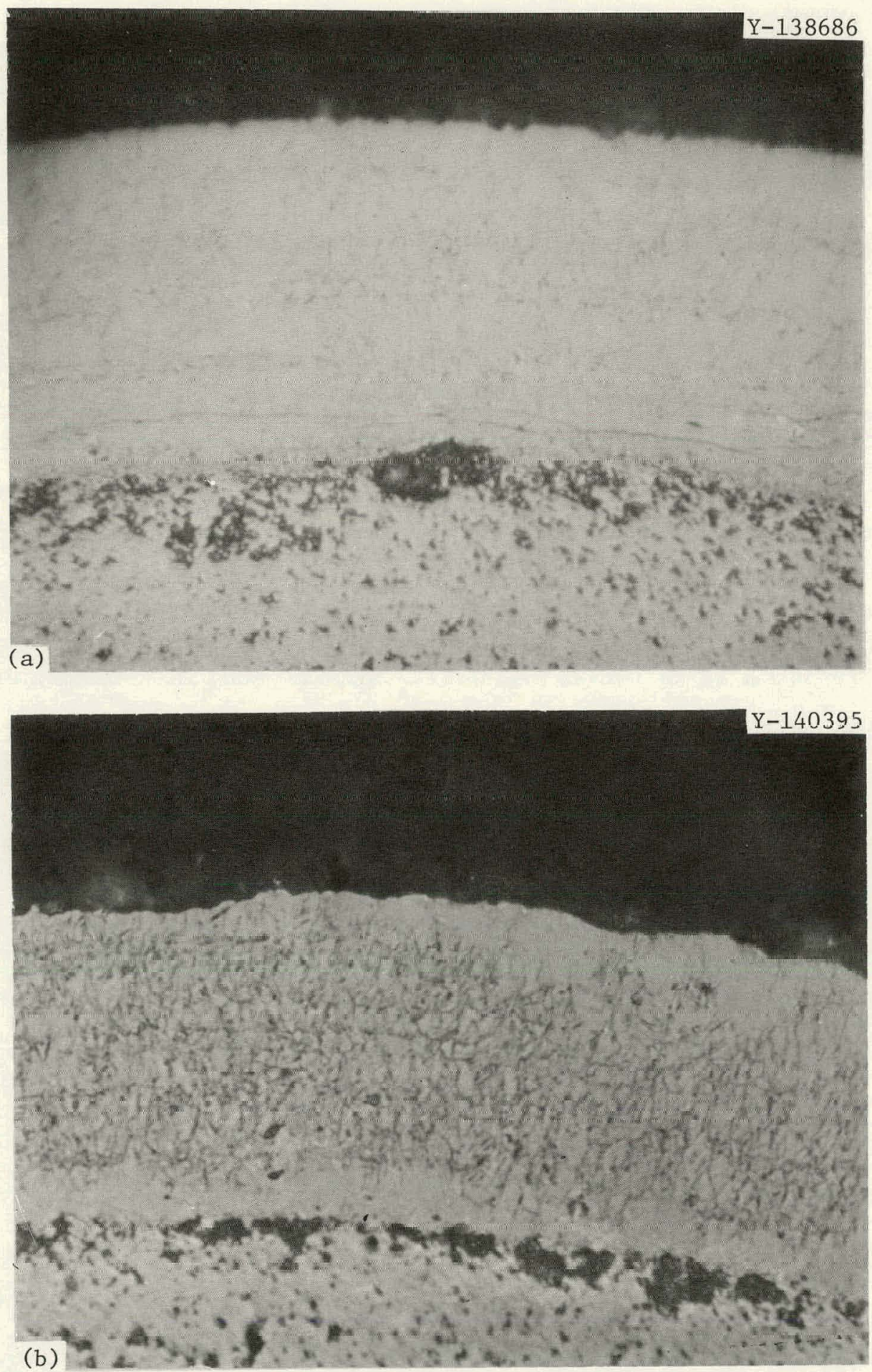

Fig. 12. Intermediate Grain Size Coatings with Little Banding Deposited Using a $\mathrm{H}_{2}$ :MTS Ratio of 45. (a) Run A-737, Flux $=0.060$ $\mathrm{cm}^{3} / \mathrm{min} \cdot \mathrm{cm}^{2}$; (b) Run A-743, Flux $=0.102 \mathrm{~cm}^{3} / \mathrm{min} \cdot \mathrm{cm}^{2}$. The deposition temperature was $1475^{\circ} \mathrm{C}$ for both coatings. 1500x. Reduced $7.5 \%$. 

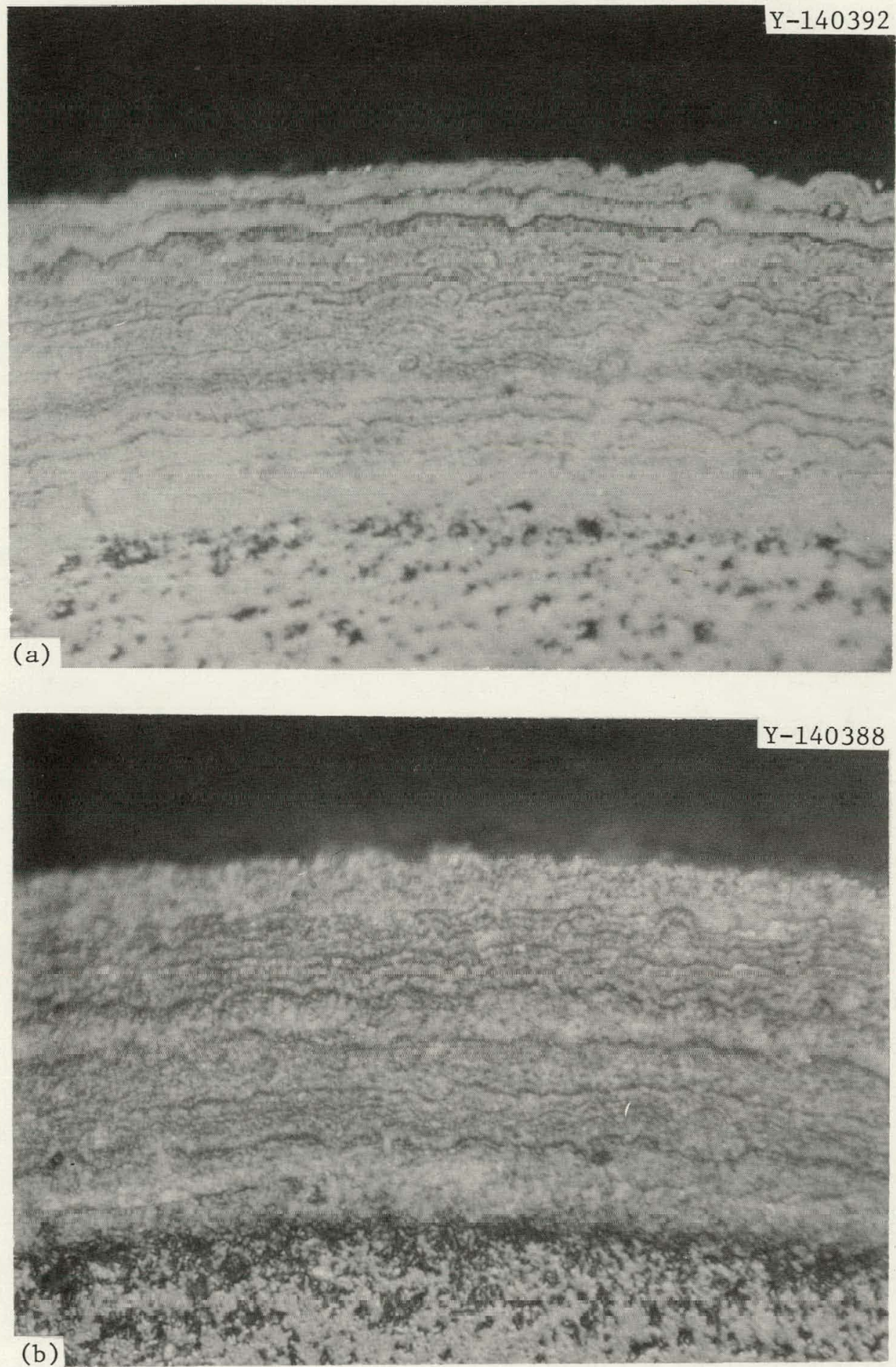

Fig. 13. Fine Grain Structure with Convoluted Banding Typical of Low Temperature Deposits. (a) Run A-740, Flux $=0.060 \mathrm{~cm}^{3} / \mathrm{min} \cdot \mathrm{cm}^{2}$, $\mathrm{H}_{2}$ : MTS ratio $=45, \mathrm{~T}=1405^{\circ} \mathrm{C}$; (b) Run A-736, Flux $=0.085 \mathrm{~cm}^{3} / \mathrm{min} \cdot \mathrm{cm}^{2}$, $\mathrm{H}_{2}$ :MTS $=65, \mathrm{~T}=1475^{\circ} \mathrm{C}$. The actual deposition temperature for A-736 was snmewhat lower than $1475^{\circ} \mathrm{C}$ because of the high gas flow rate. $1500 \times$. 
$3.195 \mathrm{~g} / \mathrm{cm}^{3}$. Coatings produced at higher temperatures (about $1675^{\circ} \mathrm{C}$ ) show much larger grains. The coatings in Fig. 14 show large columnar grains and have a high density $\left(3.195 \mathrm{~g} / \mathrm{cm}^{3}\right)$.

The correlation of crushing strength and grain size is important. As would be expected, small grain size gives high strengths while very large grains yield low strengths.

\section{FRACTION DEFECTIVE}

A silicon carbide particle coating is said to be defective it the silicon carbide layer is cracked or partially or completely missing. The fraction of the particles that have defective silicon carbide layers can be measured by two techniques. The first and most commonly used technique is a burn and acid leach. This method uses a burn or oxidation to remove the outer carbon coating and also to remove the inner carbon layers from those particles that have defective silicon carbide layers. An acid leach is then used to dissolve the kernel. The total number of cracked particles is subsequently determined by analysis of the leach solution for uranium. Use of this technique indicated that most of the coatings had defective fractions of about $5 \times 10^{-5}$ (Table 2). Only one batch was found to have a large number of defective particles by the burn and aqueous leach technique. Coatings for this batch were deposited at a high temperature $\left(1675^{\circ} \mathrm{C}\right)$. There was no correlation between the defective fraction as determined by the burn-leach method and any of the coating parameters.

The second method determines the fraction defective by a mercury intrusion technique. ${ }^{19}$ Particles that have had the outer carbon layer removed are pressurized in mercury at $103 \mathrm{MPa}(15,000 \mathrm{psi})$ for $1 \mathrm{hr}$. Mercury passes through cracks in any defective silicon carbide coatings and saturates the outer portion of the inner carbon coatings. The particles are then $\mathrm{x}$-radiographed, and defective particles can be identified by the presence of mercury inside the silicon carbide shell. This technique showed that the average defective fraction was about $4 \times 10^{-4}$ (Table 2). Again none of the coating parameters were correlated with fraction defective. There was an indication by both techniques that 

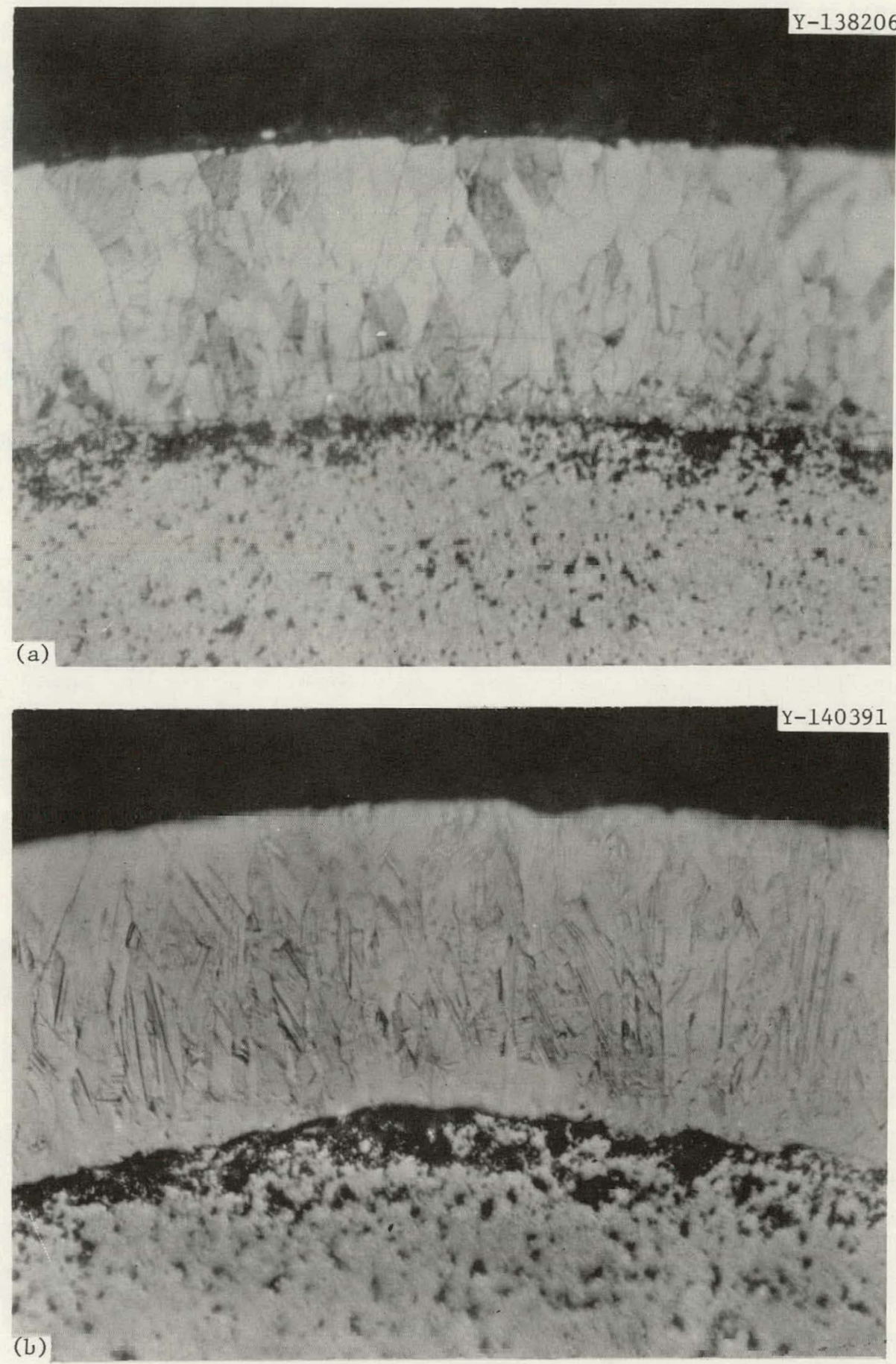

Fig. 14. Large Columnar Grains of Coatings Deposited at $1675^{\circ} \mathrm{C}$. (a) Run A-730, Flux $=0.035 \mathrm{~cm}^{3} / \mathrm{min} \cdot \mathrm{cm}^{2}$; (b) Run A-739, Flux $=$ $0.085 \mathrm{~cm}^{3} / \mathrm{min} \cdot \mathrm{cm}^{2}$. The $\mathrm{H}_{2}$ :MTS ratio was 65 for both coatings. $1500 \times$. Reduced $4.5 \%$. 
higher temperatures caused higher defective fractions. This effect was not statistically significant because the error in the measurement techniques was quite large.

The burn-leach method likely yields values which are slightly too low because of the possibility of incomplete oxidation of underlying carbon layers or because of incomplete dissolution of the uranium bearing material from the kernel of defective particles. To the contrary, the mercury intrusion technique is likely biased towards high values since occasionally intrusion of mercury into a soot ball is mistaken for a defective fuel particle. Thus, the correct value for the fraction of defective silicon carbide layers is probably within the range established by values obtained with the two methods.

Previous workers did not report on the fraction of the silicon carbide layers which were defective. Adequate irradiation performance dictates that the fraction defective be less than about one in $10^{3}$ particles. Nearly all of the coating conditions used in this study yielded less defective particles than the specified value.

\section{CONCLUSIONS}

The silicon carbide coating operation has been studied in response to the following variables: temperature, MTS flux, and $\mathrm{H}_{2}$ :MTS ratio. These coating variables were found to have an influence on density, crushing strength, uranium dispersion, coating efficiency, and the condition of the gas distributor. From this information, it has been possible to increase the deposition rate of high quality SiC from $0.2 \mu \mathrm{m} / \mathrm{min}$ to $0.5 \mu \mathrm{m} / \mathrm{min}$. The best coating conditions were determined to be a temperature of about $1575^{\circ} \mathrm{C}$, an MTS flux of $0.100 \mathrm{~cm}^{3} / \mathrm{min} \cdot \mathrm{cm}^{2}$ and a $\mathrm{H}_{2}$ : MTS ratio of 4's or greater.

\section{ACKNOWLEDGMENTS}

The careful work of C. E. DeVore and J. B. Flynn during the preparation of these particles is greatly appreciated. The authors would like to thank C. S. Yust and J. I. Federer of ORNL for reviewing the report. 
We would also like to thank George Griffith for editing and Kathryn A. Witherspoon for the final preparation of the report.

\section{REFERENCES}

1. E. Gyarmati and Nicke1, Stationary and Dynamic Deposition of Sizicon Carbide on Coated Fuel Particles, JÜL-900-RW (ORNL-TR-2733, November 1972).

2. J. I. Federer, Fluidized Bed Deposition and Evaluation of Silicon Carbide Coatings on Microspheres, ORNL/TM-5152 (January 1977).

3. T. D. Gulden, Deposition and Microstructure of Vapor Deposited Silicon Carbide, GA-8275 (December 1, 1967).

4. E. H. Voice and D. N. Lamb, The Deposition and Structure of Pyrolytic Sizicon Carbide, Dragon Project Report 677 (October 1969).

5. R. B. Pratt, J. D. Sease, W. H. Pechin, and A. L. Lotts, "Pyrolytic Carbon Coating in an Engineering Scale System," Nucl. Appl, 6(3): 241-55 (March"1969).

6. W. J. Lackey et al., "Microsphere Coatings," Gas-Cooled Reactor and Thorium Utilization Program Annual Progress Report, Sept. 30, 1971, ORNL-4760, pp. 45-52.

7. W. J. Lackey and J. D. Sease, Means for Effecting Fluidization in Pyroloytic Carbon Coating Processes (to U.S. Atomic Energy Commission) U.S. Patent 3,889,631. June 17, 1975.

8. W. J. Lackey, D. P. Stinton, and J. D. Sease, "Improved Gas Distributor for Coating HTGR Fuel Particles," to be published in Nuclear Technology; published as ORNL/TM-5731 (January 1977).

9. J. D. Sease and A. L. Lotts, Development of Processes and Equipment for the Refabrication of HTGR Fuels, ORNL-TM-5334 (June 1976).

10. G. W. Weber, R. L. Beatty, and V. J. Tennery, Properties of Carbonized and Converted Uranium-Loaded Weak-Acid Resin, ORNL-5201 (February 1977).

11. P. A. Haas, HTGR Fuel Development: Loading of Uranizm on Carboxylic Acid Cation-Exchange Resins Using Solvent Extraction of Nitrate, ORNL-TM-4955 (September 1975). 
12. W. H. Pechin et al., "Quality Control Tests for High-Temperature Gas-Cooled Reactor Recycle Fuel," International Atomic Energy Agency Seminar on Nuclear Fuel Quality Assurance, Oslo, Norway, May 24-28, 1976, Paper No. SR-713 (Proceedings in press).

13. K. Bongartz, E. Gyamati, H. Schuster, and K. Täuber "The Brittle Ring Test: A Method for Measuring Strength and Young's Modulus on Ratings of HTGR Fuel Particles." Nucl. Mater. 62: 123-27 (1976).

14. W. J. Lackey. D. P. Stinton, L. E. Dovia, and R. L. Beatty, "Crushing Strength of HTGR Fuel Particles," Nucl. Technol. 31(2): 1.91-2.n1 (Novcmber 1976).

15. G. W. Weber, R. L. Beạtty, V. J. Tennery, and W. J. Lackey, Uranium Dispersion in the Coating of Weak-Acid-Resin-Derived HTGR Fuel Microspheres, ORNL/TM-5133 (February 1976).

16. R. W. McClung, "Studies in Contact Microradiography," ORNL-3511 (October 1963).

1.7. W. H. Pechin and J. E. Mack, Automatic Particle Size Analysis of HTGR Recycle Fuel, GCR 76/21 (June 1976).

18. Personal Communication with J. Holder, C.E.N., Grenoble, France, April 1975.

19. D. M. Hewerte II and W. R. Laing, "Dctection of Defective SiC Tayprs in Coated Nuclear Fuel Particles," Nucl. TBohnol. 21: 149 (1974). 
ORNL/TM $=5743$

Distribution

Category UC-77

\section{INTERNAL DISTIBUTION}

1-2. Central Research Library

3. Document Reference Section

4-11. Laboratory Records Department

12. Laboratory Records, ORNL RC

13. ORNL Patent Office

14. P. Angelini

15. B. J. Baxter

16. R. L. Beatty

17. E. S. Bomar, Jr.

18. B. J. Bolfing

19. R. A. Bradley

20. C. R. Brinkman

21. A. J. Caputo

22. J. A. Carpenter

23. J. H. Coobs

24. D. Costanzo

25. J. E. Cunningham

26. F. C. Davis

27. J. H. DeVan

28. C. E. DeVore

29. J. R. DiStefano

30. R. G. Donnelly

31. W. P. Eatherly

32. J. I. Federer

33. P. A. Haas

34. L. A. Harris

35. C. C. Haws

36. R. L. Hamner

37-39. M. R. Hill

40. F. J. Homan

41. D. R. Johnson

42. M. J. Kania

43-44. P. R. Kasten

45-49. W. J. Lackey

50. D. E. LaValle

51. B. C. Leslie

52. T. B. Lindemer

53. A. L. Lotts

54. J. E. Mack

55. M. M. Martin
56. R. W. McClung

57. H. E, McCoy

58. D. L. McElroy

59. C. J. McHargue

60. S. R. McNeany

61. C. S. Morgan

62. M. T. Morgan

63. K. J. Notz

64. A. R. O1sen

65. A. E. Pasto

66. P. Patriarca

67. R. L. Pearson

68. H. Postma

69. J M Robbins

70. J. E. Rushton

71. T. F. Scanlan

72. A. C. Schaffhauser

73. J. L. Scott

74. J. E. Selle

75. J. H. Shaffer

76. J. W. Snider

77. J. 0. Stiegler

78-80. D. P. Stinton

81. R. R. Suchomel

82. V. J. Tennery

83. S. M. Tlegs

84. T. N. Tiegs

85. D. B. Trauger

86. G. C. Wei.

87. J. R. Weir, Jr.

88. J. W. Woods

89. R. G. Wymer

90. R. M. Young

91. C. S. Yust

92. R. W. Balluffi (consultant)

93. P. M. Brister (consultant)

94. W. R. Hibbard, Jr. (consultant)

95. H. Palmour III (consultant)

96. N. E. Promisel (consultant)

97. D. F. Stein (consultant) 
EXTERNAL DISTRIBUTION

98-99. ERDA DIVISION OF REACTOR NUCLEAR RESEARCH AND APPLICATIONS, Washington, DC 20545

Director

100. ERDA IDAHO OPERATIONS OFFICE, P.0. Box 2108, Idaho Falls, ID 83401

Barry Smith

101. ERDA OFFICE OF PROGRAM MANAGEMENT, RESEARCH AND SPACE PROGRAMS, P.o. Box 81325, San Diego, CA 92138

J. B. Radcliffe

102. ERDA SAN FRANCISCO OPERATIONS OFFICE, 1333 Broadway, Wells Fargo Building, Oakland, CA 94612

R. D. Thorne, Manager

103-106. ERDA DIVISION OF WASTE MANAGEMENT, PRODUCTION AND PROCESSING, Washington, DC 20545

Acting Assistant Director for Reprocessing

Chief, Technology Branch

Chief, Projects Branch

Chief, Industrial Programs Branch

107-109. ERDA OAK RIDGE OPERATIONS OFFICE, P.O. BOX E, Oak Ridge, TN 37830

Director, Research and Technical Support Division

Director, Reactor Division

F. E. Dearing, Reactor Division

110-291. ERDA TECHNICAL INFORMATION CENTER, P.0. Box 62, Oak Ridge, TN $3 \overline{7} 830$

For distribution as shown in TTD-4500 Distribution

Categnry,

UC-77 - Gas-Cooled Reactor Technology

292-299. ERDA Exchange Agreements with Germany and Dragon Project 